\title{
Sustainable Usage of Waste Materials in Aerated and Foam Concrete: A Review
}

\author{
Indu Susan Raj, Karthiyaini Somasundaram* \\ School of Civil Engineering (SCE), Vellore Institute of Technology, Chennai Campus, Chennai - 600127, India
}

Received April 4, 2021; Revised May 18, 2021; Accepted June 15, 2021

\section{Cite This Paper in the following Citation Styles}

(a): [1] Indu Susan Raj, Karthiyaini Somasundaram, "Sustainable Usage of Waste Materials in Aerated and Foam Concrete: A Review," Civil Engineering and Architecture, Vol. 9, No. 4, pp. 1144-1155, 2021. DOI: 10.13189/cea.2021.090416.

(b): Indu Susan Raj, Karthiyaini Somasundaram (2021). Sustainable Usage of Waste Materials in Aerated and Foam Concrete: A Review. Civil Engineering and Architecture, 9(4), 1144-1155. DOI: 10.13189/cea.2021.090416.

Copyright $\mathrm{C} 2021$ by authors, all rights reserved. Authors agree that this article remains permanently open access under the terms of the Creative Commons Attribution License 4.0 International License

\begin{abstract}
The utilization of waste materials in concrete is now a widely used concept that counteracts the depletion of natural resources. In addition to this, it will untangle the disposal of waste materials in nature and find an alternative approach to shelter the environmental resources. Due to rapid growth in industrialization, waste management has become increasingly challenging in recent years. Several waste materials could be used in whole or in part to replace cement or aggregates. The main disadvantage of conventional concrete is its increased self-weight. The paper summarizes the current knowledge of two types of lightweight concrete, viz aerated and foam concrete that can be made less dense than conventional concrete and the possibility of using waste materials. The usage of admixtures like Fly ash, GGBS, silica fume, and waste materials like quarry dust, rubber particles, rice husk ash, plastic waste, glass powder, and foundry sand is examined. The effective use of waste materials in lightweight concrete is reviewed by evaluating properties such as workability, elastic modulus, compressive strength, flexural strength, and microstructural characteristics. The optimum percentage of Fly ash, GGBS, silica fume, and rice husk ash is found to be $20 \%, 50-75 \%$, greater than $10 \%$, and 20 $-30 \%$, respectively. Out of different types of plastic waste used in concrete, $\mathrm{PVC}$ granules that pass $5 \mathrm{~mm}$ sieve size are used to prepare lightweight aggregate concrete, which exhibits a density of around $1500 \mathrm{~kg} / \mathrm{m}^{3}$. The quarry dust is the best option for an acceptable aggregate replacement at $20 \%$ in foam concrete. The studies show a drastic increment in compressive strength and capillary absorption is also increased to $14 \%$ than conventional cement, which
\end{abstract}

reduced the risk of early-age cracking. Fine aggregate replaced of glass powder exhibits delay in setting time at higher percentages. While using $20 \%$ of fine aggregate substituted with foundry sand yields comparable results to the control specimen in terms of their mechanical properties

Keywords Aerated Concrete, Foam Concrete, Rubber Particles, Plastic Waste, Quarry Dust, Fly Ash, GGBS

\section{Introduction}

The most popularly utilized construction material is concrete, and its usage rises annually due to its enhanced properties. The density of conventional concrete is about $2500 \mathrm{~kg} / \mathrm{m}^{3}$. Lightweight concrete is characterized as concrete that can be made less dense than conventional concrete by adopting various methods. Lower density leads to a decline in self-weight, which helps in the reduction of dead load. From a structural development viewpoint, lighter material can decrease the entire load of the establishments, which is a huge factor, especially in high-rise structures, thereby reducing the development cost, lower haulage, and easy handling. Lightweight concrete likewise has less thermal conductivity, which improves with a decline in density. Lightweight concrete is categorized according to the manufacturing process as lightweight aggregate concrete, in which porous lightweight aggregates are used; aerated concrete produced by introducing large voids within the concrete 
by air-entraining, and no fines concrete omitting fine aggregates so that numerous voids between the particles are present. Based on its usage, lightweight concrete is summarized as structural lightweight concrete (load-bearing) and non-structural lightweight concrete (non-load bearing like walls for insulation purposes).

Voids accomplish the decrease in concrete density in either the aggregates or in the mortar or coarse particle interstices. The voids present in it will result in the strength reduction of lightweight concrete compared with ordinary concrete. The lightweight concrete is the best option as a construction material, where high strength is not essential, and also, it is an excellent thermal and sound insulator. The advantages of lightweight concrete will override its disadvantages like less resistance to abrasion, apparently more expensive than ordinary concrete, and requires more care and attention in mixing, handling, and placing. Now the usage rate of lightweight concrete increased worldwide, and studies are getting on because of its new and innovative applications.

\subsection{Aerated Concrete}

Aerated concrete is nearly homogenous compared to conventional concrete, which does not have a coarse aggregate phase. Being this, it demonstrates an enormous variety in its properties. The aerated concrete properties are impacted by curing methods utilized, techniques adopted for pore arrangement formation, and the microstructure and composition displayed. Aluminum powder is the most generally utilized air-entraining specialist, although hydrogen peroxide, bleaching powder, and calcium carbide can likewise be used, which correspondingly liberates hydrogen, oxygen, and acetylene [1]. While using Aluminum powder as an air-entraining agent, the workability is significantly reduced, and the fineness of Aluminum powder and the water-binder ratio also influences the aeration characteristics. At a lower water-cement ratio and with the constant fineness of Aluminum powder, the specified density cannot be achieved since the mix is too hard while the hydrogen gas produced cannot stay within the mix. But at a higher water-cement ratio that is at 0.6 and above, and with a constant fineness of Aluminum powder, the required density can be achieved [2]

\subsection{Foam Concrete}

Foam concrete is defined as a cementitious material that comprises at least 20 percent of foam. The foam is entrained mechanically into the mortar in the plastic state and maintains the dry density between 300 to $1600 \mathrm{~kg} / \mathrm{m}^{3}$. Foam concrete differs from aerated concrete by the amount of air-entrained. In the case of aerated concrete, air-entrained is about 3 to 8 percentage while in the case of foam concrete, it is almost 20 percentages. The recognized benefits of foam concrete include flowing ability, acoustic properties, fire resistance, and heat-protecting properties. Foam concrete is found to be used in filling empty spaces, for example, holes, vaults due to their moderately great strength and easily removable nature [3]. It does not require any vibration or compaction while filling as it holds enough ability to flow and self-compacting nature.

Lower E- value (Young's Modulus) is observed when foam concrete with higher coarse aggregate is used, compared to the fine aggregate, because of the interaction between paste and porous aggregates. Higher sand content increases the strength of foam concrete as there may be a difference in the pore size of the paste [4]. Another variant of foam concrete is the ultra-lightweight foam concrete which possesses a density between $100-300 \mathrm{~kg} / \mathrm{m}^{3}$ which can be developed using ordinary Portland cement and Fly ash, hydrogen peroxide, and chemical admixtures [5]. With the assistance of materials like slag cement, Fly ash, silica fumes, the mix design stability and long-term strength of the concrete are improved. Even though a long time is required for Fly ash replaced concrete to reach its full strength compared to conventional concrete. It is observed that supplementary cementitious materials can be used up to $67 \%$ as a replacement with cement. The type of filler material can influence the performance of foam concrete. When the filler material is fine, a restricted air distribution may get created, which will increase the compressive strength. Therefore, the sort of filler material included and properties depending on it like water/solid proportion, binding material content, foam volume principally impacts the compressive strength. If the air-void distribution is even and uniform, the foam concrete exhibits higher strength [6]. The uniform air-void distribution will be exhibited by a lower level of foam volume than a higher level of foam content [7].

It is observed that if the water content is low, cement will absorb the water from the foam resulting in the breakage of the air bubbles. In the case of excess water content, segregation happens during casting. Additionally, it is found that the foam volume needed is less when fly ash is added to the mix, which also exhibits an improved strength to density values [8]. It is suggested that an optimum water-cement ratio that ranges from $0.5-0.6$ can be adopted. The water-cement ratio should be maintained between 04-1.25 to maintain a lower density. When Fly ash is added to concrete, the spread value increases by 2.5 times. This is because of the particle size and shape. The density will also be influenced by this exponentially [9]. Again, the superplasticizers employed in the mix also affect its properties like workability and stability. It is observed that a proper mix of superplasticizer and added substances have been found to affect the void structure of foam concrete. The overlapping and merging of bubbles can be significantly reduced when the constituents become more refined with the probability of obtaining a uniform coated paste on the bubble [10]. 
This paper discusses various waste materials that are usually used in concrete as a replacement to cement and fine aggregate, which can be used in aerated and foam concrete. Many studies are conducting based on this to find out the viability of using these waste materials effectively. This is sometimes turned out to be a remedy to the economic and environmental problems faced by developing countries due to depleting resources.

\section{Sustainable Usage of Waste Materials in Concrete}

\subsection{Waste Materials as a Replacement for Cement}

Nowadays, several materials are used as a substitute to cement worldwide. The replacements are used to impart economy, improved durability, different colors, and most importantly, a lower impact on nature than using ordinary Portland cement [11]. These are used to enhance specific properties that are desirable under given circumstances [12]. The materials which are discussing in this paper that can be used as a replacement to cement are Fly ash, GGBS, silica fume, and rice husk ash and focuses on analyzing the possibility of using this in aerated and foam concrete.

\subsubsection{Fly Ash}

Fly ash is the finely powdered residue produced from the combustion of powdered coal, floats out of the combustion chamber with exhaust gases, and is collected by emission control such as electrostatic precipitator and scrubbers. It is considered the most used pozzolanic material. The application of fly ash in concrete has impacted the technical properties and contributes to environmental pollution control [13]. Fly ash is broadly classified into Class $\mathrm{F}$ and Class $\mathrm{C}$, and this classification is based on its calcium content [14].

\subsubsection{Fresh Properties of Concrete}

The primary influence of Fly ash on the fresh properties of concrete is water demand and workability. The reduction in water demand of concrete in the presence of Fly ash usually is about 5 and $15 \%$ compared to the control mix for steady workability. The studies revealed that after $20 \%$ of replacement, there is a considerable effect on the mechanical properties [15]. Cement with $30 \%$ fly ash exhibits more absorption than with a $20 \%$ replacement. It is concluded that the volume of Fly Ash does not show much significance in the porosity strength relationship of cellular lightweight concrete [16].

\subsubsection{Hydration Characteristics}

The hydration product developed after mixing Fly ash, cement, and water is very similar to that produced while mixing cement and water alone. However, the microstructure is denser as the mix is less permeable. The reaction with water does not start immediately after mixing; it will start only when the $\mathrm{pH}$ level of pore water reaches 13.2. This could take a week or more to complete [17]. Thus, the reaction procedure of Fly ash incorporated concrete is prolonged. Therefore, the specimen needs more wet curing. At higher temperatures, the reactions with Fly ash increase but usual strength reduction will occur [18]. Thus prolonged reaction characteristics can be used effectively, especially at higher percentages of air entrainment because there is a chance of segregation of constituents at higher percentages.

\subsubsection{Strength Development Characteristics}

The reactions of Fly ash are affected by the nature of Portland cement used for replacement. The impact of Fly ash has a physical effect of improving the microstructure properties of the hydrated cement paste in addition to the effect of chemical reactions. The coarser particles of Fly ash improve the density of hydrated cement paste, which results in strength development, crack propagation resistance, and stiffness. The resulting capillary pores could retain water which helps to achieve long-term hydration. It is found that after $20 \%$ of the replacement of cement with Fly ash, there is not much influence on water demand.

The limiting content of Fly ash is kept as $30 \%$, as more amount of Fly ash does not show much influence on the strength development characteristics. The creep and shrinkage do not affect by the replacement with Fly ash [12].

\subsubsection{Durability Aspects}

The ingredients used in concrete affect the durability characteristics of concrete. Initially, the permeability of concrete with Fly ash is higher than the concrete without Fly ash, but this will be reduced as time is prolonged [17]. The alumina and silica contribute to sulfate reactions by forming expansive ettringite. By removing calcium hydroxide, Class Fly ash improves its sulfate resistance at percentage content between 25 to $40 \%$ of final cementitious material. In the case of air-entrained concrete, almost $60 \%$ of cement replacement with Class F Fly ash exhibits good resistance to freezing and thawing at a water-cement ratio of 0.33 . The resistance is found to be weakened while using Class C Fly ash [19]. At the water-cement ratio between 0.27 and 0.39 , and $60 \%$ of cement replacement with Fly ash, the specimen exhibits good resistance to chloride penetration [20]. If Fly ash is used in an adequate amount, the alkali-aggregate reaction is considerably reduced. Fly ash itself contains alkalis, but only about one-sixth is water-soluble. It is found that there is no beneficial effect of Fly ash concerning the alkali -carbonate reaction [21].

\subsubsection{Ground Granulated Blast Furnace Slag}

Babu [22] studied the efficiency of GGBS on concrete 
and tried to demonstrate the 28 days cementitious output of ground granulated blast furnace slag (GGBS) in concrete at the different replacement percentages and concluded that the overall strength is reduced for percentage variations from 10 to 80 . Again, a fast method of construction with high-strength concrete containing GGBS is studied by Barnett [23] in which fine sand as fine aggregate is used for this study. In this, half of the total amount of specimen is used for 28 days of compressive strength testing, and the other half of the specimens are kept in a humidity-controlled chamber (adiabatic temperature). The early age strength of concretes with 28 -days cured at $200^{\circ} \mathrm{C}$ was adversely affected by the increased cement replacement levels with GGBS. By high-temperature curing, the early age strength contribution of GGBS is improved. Arivalagan [24] has done a study on strength variations at various replacement levels of GGBS and its effectiveness in concrete and concluded that, at an early age, the strength is lower and continues to gain strength over a long period of time. This gain strength is due to the smaller grain size of GGBS particles than cement [25].

\subsubsection{Fresh Properties of Concrete}

GGBS in concrete increases workability, but the mix was found to be more cohesive. This is because of the smooth surface nature of GGBS particles and thus absorbs less water during mixing. It is also because of the superior dispersion quality of the cementitious particles found in GGBS. It is also found that the mix leads to retardation at average temperatures [26]. The aerated and foam concrete, which are discussing in this paper, requires adequate workability as this will not undergo any vibration or compaction. So GGBS can be effectively used as a replacement for developing sustainable lightweight concrete.

\subsubsection{Hydration and Strength Development}

The hydration depends on the breakdown of the glass content present in supplementary cementitious particles resulting in a denser microstructure and long-term strength [27]. That is, about $37 \%$ of GGBS is hydrated at 28 days [28]. Thus, the overall hydration temperature can be brought down by incorporating GGBS in the mix. This temperature reduction is because of the finer particles in GGBS, which can be rectified by using Portland cement with high contents of $\mathrm{C}_{3} \mathrm{~A}$ and alkalis [29]. It is reported that a good strength development can be achieved with 50 to $75 \%$ of GGBS with a total cementitious content of $300 \mathrm{~kg} / \mathrm{m}^{3}$ [30]. The relationship between the mechanical properties does not get altered by using GGBS in concrete [31]. The shrinkage is increased initially, but overall, it is not affected by using GGBS [32]. The shrinkage strain increased with higher replacement levels with GGBS [33] and the least strain with $20 \%$ replacement [34]. Based on studies, it is illustrated that autogenous shrinkage increases with GGBS replacements [35].

\subsubsection{Durability Aspects}

Divsholi [36] studied the durability properties and microstructure of GGBS cement concrete. In this study, the substitution percentage of GGBS is fixed as 10,30 and $50 \%$ at three water-cement ratios such as 0.4,0.5 and 0.6. It is shown that the compressive strength increases at 28 days of water curing [37], but the average pore size is reduced [38]. The average pore size is reduced by 15,30 , and $47 \%$, respectively, at 10,30 , and $50 \%$. Out of this, 0.6 water-cement ratios were found to be more successful. The carbonation rate is increased while replacing with GGBS at $50 \%$. This rate can be brought down by extending the period of water curing. The use of GGBS alters the morphology of cement paste. It exhibits a foil-like morphology, while Portland cement produces C-S-H gel with fibril morphology [39].

\subsubsection{Silica Fume}

Silica fume is an amorphous, highly reactive ultrafine powder collected as a by-product of the silicon and ferrosilicon alloy. The alloy is from high-purity quartz and coal in a submerged arc electric furnace. The packing density and cohesion of the mix is improved can be improved by using silica fume. Thus the bleeding tendency is reduced [12]. More than $10 \%$ replacement is more beneficial for improved concrete characteristics [40].

\subsubsection{Fresh Properties of Concrete}

The concrete mixtures with higher percentages of silica fume exhibiting a slump of $100 \mathrm{~mm}$ tend to require more dosages of superplasticizers [40]. The slump flow of concrete is improved by adding silica fume due to its ball-bearing effects. However, at a higher percentage, workability is reduced due to the enlarged surface area of particles [41]. The concrete cohesiveness makes it suitable for underwater concreting and flowing concrete. In air-entrained concrete, an increased amount of air-entraining admixture is used while incorporating silica fume. Again, there are some problems with the air void system [12], even though the entrained air remains stable [42].

\subsubsection{Hydration and Strength Development Characteristics}

The early strength development will take place when concrete is incorporated with silica fume. The early strength development is because of the quick-dissolving tendency of silica fume with a saturated solution of calcium hydroxide. The C-S-H produced, as a result, has a lower cement silica ratio than that produced with Portland cement [28]. The acceleration of the hydration process with silica fume will increase in the presence of GGBS [43].

\subsubsection{Durability Aspects}

Gruszczynski [44] studied the durability features of 
mortar modified with silica fume. The test conducted revealed that an average of $27 \%$ decreases water absorption than the control specimen, which is confirmed by 25 cycles of freeze and thaw testing. At a higher dosage of silica fume, shrinkage is thrice than the control specimen. The strength is increased at a range of 21 to $37 \%$, and flexural strength is $32 \%$. The durability properties and microstructure characteristics can be improved by using silica fume at higher percentages at $25 \%$. The improved characteristics are because of the high specific area of silica fume particles. Thus silica fume can be effectively incorporated in aerated or foam concrete.

\subsubsection{Rice Husk Ash}

Another category of waste material that can be induced in concrete as filler and additives is rice husk ash (RHA), which will be obtained as a result of incineration under controlled conditions. The formation of supplementary $\mathrm{C}-\mathrm{S}-\mathrm{H}$ gel contributes to the strength development and durability characteristics of concrete. The high porous microstructure itself contributes to the weakest point in the hardened matrix [45]. The $\mathrm{Ca}(\mathrm{OH})_{2}$ reacts with atmospheric carbon dioxide to form calcium carbonate, which improves strength formation [46]. The summarized review of RHA in concrete is listed in Table 1.

Table 1. Review on properties of RHA incorporated concrete

\begin{tabular}{|c|c|c|c|c|c|c|c|}
\hline $\begin{array}{l}\text { Author } \\
\text { (Year) }\end{array}$ & $\mathrm{W} / \mathrm{b}$ ratio & $\begin{array}{l}\text { Percentage } \\
\text { replacements }\end{array}$ & $\begin{array}{l}\text { Compressive } \\
\text { Strength (MPa) }\end{array}$ & $\begin{array}{l}\text { Splitting } \\
\text { tensile } \\
\text { strength } \\
(\mathrm{MPa})\end{array}$ & $\begin{array}{c}\text { Abrasion } \\
\text { index }\left(\mathrm{g} / \mathrm{mm}^{2}\right)\end{array}$ & $\begin{array}{l}\text { Chloride } \\
\text { penetration } \\
\text { (Charge } \\
\text { passed in } \\
\text { Coulomb) }\end{array}$ & $\begin{array}{c}\text { Sulphate } \\
\text { Exposure (MPa) }\end{array}$ \\
\hline \multirow{3}{*}{$\begin{array}{l}\text { Le et al. [46] } \\
\quad 2014\end{array}$} & \multirow{3}{*}{0.33} & \multirow{3}{*}{$5,10,15,20$} & Reference (54) & $\begin{array}{l}\text { Reference } \\
\quad(5.1)\end{array}$ & $\begin{array}{l}\text { Reference } \\
(0.009)\end{array}$ & $\begin{array}{l}\text { Reference } \\
(2800)\end{array}$ & \multirow{3}{*}{-} \\
\hline & & & Range 55 to 63 & $\begin{array}{c}\text { Range } 5.6 \text { to } \\
6.5\end{array}$ & $\begin{array}{c}\text { Range } 0.006 \text { to } \\
0.008\end{array}$ & $\begin{array}{l}\text { Range } 300 \text { to } \\
900\end{array}$ & \\
\hline & & & $\begin{array}{c}\text { Optimum } 10 \% \\
(62.3)\end{array}$ & $\begin{array}{l}\text { Optimum } \\
10 \%(6.5)\end{array}$ & $\begin{array}{c}\text { Optimum 10\% } \\
(0.006)\end{array}$ & $\begin{array}{c}\text { Optimum } \\
20 \%\end{array}$ & \\
\hline \multirow{7}{*}{$\begin{array}{c}\text { Sensale } \\
\text { [47] } 2010\end{array}$} & \multirow{7}{*}{$\begin{array}{c}0.5 \\
0.4,0.32\end{array}$} & $5,10,15$ & - & - & - & - & \\
\hline & & \multirow{3}{*}{$\begin{array}{l}\text { Residual RHA - } \\
\quad 5,10,15\end{array}$} & \multirow{3}{*}{-} & \multirow{3}{*}{-} & \multirow{3}{*}{-} & \multirow{3}{*}{ Decreases } & $\begin{array}{c}\text { w/b } 0.5 \text { at } 15 \% \\
(49 \mathrm{MPa})\end{array}$ \\
\hline & & & & & & & $\begin{array}{c}\text { w/b } 0.4 \text { at } 15 \% \\
(95 \mathrm{MPa})\end{array}$ \\
\hline & & & & & & & $\begin{array}{c}\mathrm{w} / \mathrm{b} 0.32 \text { at } 15 \% \\
(82 \mathrm{MPa})\end{array}$ \\
\hline & & \multirow{3}{*}{$\begin{array}{c}\text { Controlled } \\
\text { incinerated RHA - } \\
5,10,15\end{array}$} & \multirow{3}{*}{ - } & \multirow{3}{*}{ - } & \multirow{3}{*}{ - } & \multirow{3}{*}{ Decreases } & $\begin{array}{c}\text { w/b } 0.5 \text { at } 15 \% \\
(85 \mathrm{MPa})\end{array}$ \\
\hline & & & & & & & $\begin{array}{c}\mathrm{w} / \mathrm{b} 0.4 \text { at } 15 \% \\
(71 \mathrm{MPa})\end{array}$ \\
\hline & & & & & & & $\begin{array}{c}\mathrm{w} / \mathrm{b} 0.32 \text { at } 15 \% \\
(55 \mathrm{MPa})\end{array}$ \\
\hline $\begin{array}{l}\text { Jung et al. } \\
\text { [48] } 2017\end{array}$ & 0.48 & $\begin{array}{c}\text { (Lime powder } \\
20 \% \text { ) } \\
5,10,15 \\
\end{array}$ & Range 25 to 35 & \multirow{3}{*}{ - } & - & - & - \\
\hline \multirow{4}{*}{$\begin{array}{l}\text { Saraswathy } \\
\text { et al. [49] } \\
2007\end{array}$} & \multirow{4}{*}{0.53} & \multirow{4}{*}{$5,10,15,20,25,30$} & $\begin{array}{c}\text { Optimum } 10 \% \\
(35)\end{array}$ & & \multirow{4}{*}{-} & \multirow{4}{*}{ - } & \multirow{4}{*}{-} \\
\hline & & & $\begin{array}{c}\text { Reference } \\
(36.45)\end{array}$ & & & & \\
\hline & & & $\begin{array}{c}\text { Range } 36.49 \text { to } \\
39.55 \\
\end{array}$ & $\begin{array}{l}\text { Range } 4.57 \\
\text { to } 4.92\end{array}$ & & & \\
\hline & & & Optimum 25\% & $\begin{array}{c}\text { Optimum } \\
15 \% \\
\end{array}$ & & & \\
\hline \multirow{3}{*}{$\begin{array}{l}\text { Ganesan } \\
\text { et.al. [50] } \\
2008\end{array}$} & \multirow{3}{*}{0.53} & \multirow{3}{*}{$5,10,15,20,25$} & $\begin{array}{c}\text { Reference } \\
(37.1)\end{array}$ & & \multirow{3}{*}{ - } & $\begin{array}{l}\text { Reference } \\
(2750)\end{array}$ & \multirow{3}{*}{ - } \\
\hline & & & $\begin{array}{c}\text { Range } 35.1 \text { to } \\
42.5\end{array}$ & Range 4 to 5 & & $\begin{array}{l}\text { Range } 1000 \\
\text { to } 2500\end{array}$ & \\
\hline & & & Optimum 20\% & $\begin{array}{l}\text { Optimum } \\
20 \%\end{array}$ & & $\begin{array}{l}\text { Optimum } \\
30 \%(70 \% \\
\text { reduced })\end{array}$ & \\
\hline \multirow{3}{*}{$\begin{array}{l}\text { Kathirvel et } \\
\text { al. [51] } 2013\end{array}$} & \multirow{3}{*}{0.48} & \multirow{3}{*}{$\begin{array}{l}\text { (Lime powder } \\
\text { added) } \\
5,10,15\end{array}$} & Reference (36) & $\begin{array}{c}\text { Reference } \\
(2.5)\end{array}$ & \multirow{3}{*}{ - } & \multirow{3}{*}{ - } & \\
\hline & & & Range 15 to 25 & $\begin{array}{c}\text { Range } 2.5 \text { to } \\
4.5 \\
\end{array}$ & & & - \\
\hline & & & Optimum 10\% & $\begin{array}{c}\text { Optimum } \\
15 \%\end{array}$ & & & \\
\hline
\end{tabular}




\subsection{Waste Materials as a Replacement to Fine Aggregate}

\subsubsection{Plastic Waste}

A billion tons of varieties of plastic wastes are disposed on landfills every year, and recycling it into useful products has proven very difficult nowadays. Because of its wide availability and non-biodegradable characteristics, researches are done to incorporate it into concrete. The common forms of plastic waste used in concrete are polyethylene terephthalate (PET) bottles, scraped PVC pipes, metalized plastic wastes [52]. The magnitude of the PET bottle granules concrete is $4 \mathrm{~mm}$, which can either be used as fillers or replacements [53]. The density of PET granules is investigated to be $1390 \mathrm{~kg} / \mathrm{m}^{3}$, water absorption $0 \%$, bulk density is observed to be $844 \mathrm{~kg} / \mathrm{m}^{3}$. The fineness modulus is observed to be a little superior to that of river sand that is 4.11, since this is single graded [54].

\subsubsection{Fresh Properties}

The relationship between workability and replacement ratio of waste PET bottles in lightweight concrete illustrates that the workability increases by 52,104 , and 123 percent compared to conventional concrete at water-cement ratio 45, 49, and 53 percent, respectively. This increase is due to smooth spherical shape and the non-water absorption characteristics of PET aggregates [55]. However, the workability is found to be reduced while using metalized plastic wastes [52]. The flow value is increased, but the compressive value is decreased while using PET aggregate as fine aggregate. This impact is related to the addition of PET aggregates with elapsed time and water adsorption by unit area, which is higher than the control [56]. The slump value is maintained between $160-180 \mathrm{~mm}$ while using partial replacement of fine aggregate with PVC granules [57]. Angular and non-uniform shapes resulted in lower fluidity when shredded plastic was used. Also, it is observed that as the plastic aggregate quantity increases slump due to the availability of free water in the mix as plastic particles do not absorb water as much as conventional aggregates [58]. The consistency of the mix gets reduced with an increase in particle content [59].

\subsubsection{Hardened Properties}

The concrete characteristics using three types of PET aggregates are studied by Saikia [60]. They are coarse plastic aggregates, fine plastic aggregates, and pellet-shaped plastic aggregates. The replacement percentages are 5, 10, and $15 \%$, and found that the value of compressive strength is more significant for pellet-shaped aggregates on an average of $30 \mathrm{MPa}$ at an earlier age ( 7 days of curing) and at later ages ( 91 days) compressive strength increases by $18 \%$. PVC granules prepared by crushing PVC pipes and $95 \%$ passing $5 \mathrm{~mm}$ sieve size are used to prepare lightweight aggregate concrete, which exhibits a density around $1500 \mathrm{~kg} / \mathrm{m}^{3}$. The corresponding compressive strength is obtained on an average of $34 \mathrm{MPa}$ at 91 days of the curing period. The splitting tensile strength is found to be lower, and it is on the scale of $3 \mathrm{MPa}$. The specimens show improvement in ductility characteristics because of the decrease in elasticity and an increase in Poisson's ratio [61].

According to plastic manufacturers in Europe, the largest plastic ingredient is low-density polyethylene (LDPE), which is about $23 \%$. The percentages are followed by of high-density polyethylene (17.3\%), polypropylene $(18.5 \%)$, polystyrene $(12.3 \%)$, polyvinyl chloride $(10.7 \%)$, polyethylene terephthalate $(8.5 \%)$ and $9.7 \%$ other type. The main advantage of using plastic as aggregate is its lightweight. In addition to this, its benefits include a reduction in fuel consumption in transportation, resistance to chemical attack, and its impact on thermal and electrical insulation properties 58].Based on researches reviewed, the compressive strength is reduced with the increasing plastic content. The reduction may be due to poor bonding properties of plastic aggregates and cement paste and lower strength characteristics of plastic aggregates. The decrease in bulk density was directly proportional to the content of plastics [62]. Choi [56] while studying the density variation by replacing PET bottles, the same phenomenon was observed, in which PET aggregates are replaced with $0 \%, 25 \%, 50 \%, 75 \%$ by volume of fine aggregate revealed that the failure type has become more ductile with the increasing plastic content.

Batayneh [61] investigated the slump of concrete in which grounded plastic is used and concluded that the slump value decreases with increased plastic content. The shape of the plastics also influences this characteristic [62]. Even though there may be a decrease in strength $(3 \mathrm{MPa})$ of concrete while incorporating plastic aggregates as fine aggregate, the micro-cracks get arrested. Hence, the density is reduced (on an average of $1200 \mathrm{~kg} / \mathrm{m}^{3}$ ), an added advantage for lightweight concrete. It is observed that the pore size became more prominent and irregular at all densities as the bubbles are merging. The use of plastic waste in concrete can alter the properties of concrete, and this, the accumulating plastic waste can be reused and thus reduce the use of natural resources [63]. While using metalized microfibers, it is illustrated that the compressive strength and flexural strength do not get affected up to $1 \%$ of the dosage of the mix, but the splitting tensile strength is found to be improved [52].

\subsubsection{Rubber Particles}

The waste rubber particles are another environmental hazard. Billions of tires presently abide in landfills and illegal deposits everywhere throughout the world. The leading cause of these tires is that it releases a large volume of toxic chemicals. In addition to this, it is a breeding area for mosquitoes in entrapped water, resulting in health risks. Therefore, various studies are conducted to 
incorporate rubber particles in concrete. The rubber particles can be utilized as fillers as well as replaced with fine aggregates. There are mainly three forms of rubber that can be used for concreting like ash rubber, crumb rubber, and tire chips. The workability of the mix with rubber content has not been significantly influenced. The compressive strength will get degraded as time passes in rubberized concrete, but low density (less than $1000 \mathrm{~kg} / \mathrm{m}^{3}$ ) can be achieved [64].

The waste tire can be used in different forms like spheroid and fibers in concrete, which advances sustainability in the construction field by utilizing environmental hazard-causing material without draining natural assets. From the studies, it is illustrated that fiber-shaped tire particles show a more significant reduction in density (34.6\%) than spherical ones (19.2\%) at $30 \%$ of replacement with fine aggregates due to the higher density of spherical particles [65]. It is widely investigated that the compressive strength reduces $(70 \%)$, and water absorption $(32 \%)$ increases due to weak adhesion of tire particles with cement. The less stiffness and poor surface texture of rubber particles promote low adhesion with the cement matrix [66]. This causes poor bonding between the rubber and cement paste making ITZ brittle, contributing to micro-cracking [67]. Also, these rubber composites have a lower density than conventional concrete. The density decrease is related to entrapped air throughout the irregular and uneven surface of the rubber [68]. An advantage over this is the decrease in crack initiation and width of micro-crack [64]. Thomas [69] studied the influence of crumb rubber in concrete by replacement from $2.5 \%$ to $20 \%$, and it found that at $20 \%$ replacement, the compressive strength attained is around $30 \mathrm{MPa}$ at 28 days which reaches up to $33 \mathrm{MPa}$ at 90 days of curing. The flexural strength, the value reaches up to $5.5 \mathrm{MPa}$ at $20 \%$ replacement, and water absorption is obtained to be 0.74 . The abrasion resistance is 0.96 for $20 \%$ replacement with crumb rubber. Researchers have also reported that the compressive strength of fine granules is greater than crumb rubber of the same density [70]. The advantage of using rubber particles in aerated and foam concrete helps reduce the density of concrete.

\subsubsection{Quarry Dust}

Recently studies have been organized to examine the utilization of quarry dust as a replacement for natural aggregate. The experiment is done in conventional concrete casting practices. Quarry dust, which is available in large quantities in onsite and offsite locations, is a by-product of stone cutting, grinding, sieving, and crushing, creates several environmental problems. It results in lower energy consumption and greenhouse gas emissions. About $30 \%$ of the total volume of stone waste is rock quarrying. This vast amount is dumped as landfills causing damage to the environment and risk to human well-being.

A method of solving the aforementioned issue is to use it as an aggregate in concrete. While using quarry dust, it is observed that there is no bleeding in fresh states because of the elongated shape and high surface area exhibited by quarry dust [71]. The quarry dust can be the best option for an acceptable aggregate replacement as the studies show a drastic increment in compressive strength. Thus it can be successfully incorporated in the manufacture of lightweight concrete [72]. This increment is also obtained to evaluate the flexural strength of concrete while using quarry dust as a replacement [73]. Medina [74] studied the durability aspects of quarry dust blended cement. There is no alkali-silica reactivity present in granite quarry dust. Strength is reduced for materials having granite quarry dust which is due to its slow pozzolanic activity. Cement having $20 \%$ granite quarry dust are found to meet the strength requirements. The electrical resistivity and capillary absorption are increased to $17 \%$ and $14 \%$, respectively, than conventional cement concrete, which implies the corrosion resistance capacity. Also, the pore density and compressive strength can be increased by incorporating quarry dust in foam concrete [75].

\subsubsection{Foundry Sand}

Foundry sand is silica sand of high quality with uniform physical properties, and it is a by-product of the nonferrous and ferrous metal casting industry. Its thermal conductivity characteristics are used extensively as a moulding material, which can be recycled and reused several times. When it cannot be recycled anymore, it is discarded from the foundries, which can be used as a substitute for fine aggregates in the construction industry. The industry from which is discarded and the casting process through which it undergoes greatly influences the attributes of foundry sand. The significant generators of foundry sand are the automotive industries and their manufacturing units [76]. The summarized review of foundry sand in concrete is listed in Table 2. 
Table 2. Review on the properties of foundry sand incorporated concrete

\begin{tabular}{|c|c|c|c|c|c|c|c|c|c|c|}
\hline Author (Year) & $\begin{array}{l}\text { Water-cem } \\
\text { ent ratio }\end{array}$ & $\begin{array}{l}\text { Type of } \\
\text { replacement }\end{array}$ & Percentages & $\begin{array}{l}\text { Slump } \\
(\mathrm{mm})\end{array}$ & $\begin{array}{l}\text { Average } \\
\text { fresh } \\
\text { density } \\
\left(\mathrm{kg} / \mathrm{m}^{3}\right) \\
\end{array}$ & $\begin{array}{l}\text { Superplastici } \\
\text { zer }\end{array}$ & $\begin{array}{l}\text { Compressive } \\
\text { strength } \\
\text { (MPa)-28days }\end{array}$ & $\begin{array}{l}\text { Splitting tensile } \\
\text { strength } \\
\text { (MPa)- } \\
28 \text { days }\end{array}$ & $\begin{array}{l}\text { Flexural Strength } \\
\text { (MPa)- } \\
28 \text { days }\end{array}$ & $\begin{array}{l}\text { Modulus of } \\
\text { Elasticity (GPa)- } \\
28 \text { days }\end{array}$ \\
\hline $\begin{array}{c}\text { Torres et al. [77] } \\
2017\end{array}$ & 0.4 & $\begin{array}{l}\text { Course FS, } \\
\text { Fine FS, } \\
\text { Coarse and } \\
\text { Fine FS }\end{array}$ & $\begin{array}{l}10,20,30 \\
10,20,30 \\
20,40,60\end{array}$ & $85-100$ & 2300 & $\begin{array}{l}\text { Glenium } \\
3030\end{array}$ & $\begin{array}{l}\text { CFS: } 50 \text { to } 51 \\
\text { (increase); FFS: } \\
50 \text { to } 53 \\
\text { (increase); } \\
\text { CFFS: } 50 \text { to } 40 \\
\text { (decrease) }\end{array}$ & $\begin{array}{c}\text { CFS: } 4 \text { to } \\
4.5 \text { (increase); FFS: } 4 \\
\text { to } 5 \\
\text { (increase); CFFS: } 4 \text { to } \\
\text { 3(decrease) }\end{array}$ & $\begin{array}{l}\text { CFS: } 4.52 \text { to } 4.81 \\
\text { (increase); } \\
\text { FFS: } 4.68 \text { to } 5 \\
\text { (increase); } \\
\text { CFFS: } 4 \text { to } 2.9 \\
\text { (decrease) }\end{array}$ & $\begin{array}{c}\text { CFS: } 40 \text { to } 45 \\
\text { (increase); FFS: } 40 \\
\text { to } 50 \\
\text { (increase); CFFS: } \\
43 \text { to } 35 \\
\text { (decrease) }\end{array}$ \\
\hline $\begin{array}{c}\text { Siddique et al. } \\
\text { [76 ] } 2009\end{array}$ & 0.5 & Used FS & $10,20.30$ & $80-90$ & 2300 & $\begin{array}{c}\text { Melamine } \\
\text { based }\end{array}$ & $\begin{array}{c}29 \text { to } \\
\text { 32(increases) }\end{array}$ & 2.85 to 3 (increases) & $\begin{array}{c}4 \text { to } 4.18 \\
\text { (increases) }\end{array}$ & $\begin{array}{l}26.75 \text { to } 28.4 \\
\text { (increases) }\end{array}$ \\
\hline $\begin{array}{l}\text { Prabhu et al. [78] } \\
2014\end{array}$ & 0.44 & Used FS & $10,20,30,40,50$ & $\begin{array}{l}\text { Average } \\
80\end{array}$ & $(-)$ & $(-)$ & $\begin{array}{c}\text { Ref } 33.14, \\
\text { Range } 33.24 \text { to } \\
25.23\end{array}$ & $\begin{array}{c}\text { Ref } 2.765 \\
\text { Range } 2.612 \text { to } 2.214\end{array}$ & $\begin{array}{c}\text { Ref } 4.087, \\
\text { Range } 3.986 \text { to } \\
3.656\end{array}$ & $(-)$ \\
\hline $\begin{array}{c}\text { Manoharan et } \\
\text { al .[79] } 2018\end{array}$ & 0.5 & Used FS & $5,10,15,20,25$ & $80-100$ & 2300 & $(-)$ & $\begin{array}{c}\text { Ref } 24.8, \\
\text { Optimum } 26.5 \\
\text { Range } 26.5 \text { to } 20\end{array}$ & $\begin{array}{l}\text { Ref } 2.2, \text { Optimum } 2.8 \\
\text { Range } 1.9 \text { to } 2.8\end{array}$ & $\begin{array}{c}\text { Ref } 4.84, \\
\text { Optimum } 5.20, \\
\text { Range } 5 \text { to } 4.75\end{array}$ & $\begin{array}{c}\text { Ref } 23.6, \\
\text { Optimum } 25.4, \\
\text { Range } 23 \text { to } 25.5\end{array}$ \\
\hline $\begin{array}{c}\text { Sua-iam et } \\
\text { al .[80] } 2019\end{array}$ & $0.35,0.45$ & RHA and FS & $\begin{array}{l}\text { RHA-10,20 } \\
\text { FS -30,50 }\end{array}$ & 70 & $\begin{array}{l}2400 \\
2300\end{array}$ & Type G & 30 to 55 & 4 to 6.5 & $(-)$ & $(-)$ \\
\hline
\end{tabular}

Table 3. Review on the properties of glass powder incorporated concrete.

\begin{tabular}{|c|c|c|c|c|c|c|c|c|c|c|}
\hline Author (Year) & $\begin{array}{l}\text { Water-Cemen } \\
\text { t Ratio }\end{array}$ & $\begin{array}{l}\text { Type of } \\
\text { replacement }\end{array}$ & Percentage & $\begin{array}{l}\text { Slump } \\
(\mathrm{mm})\end{array}$ & $\begin{array}{c}\text { Average fresh } \\
\text { density } \\
\left(\mathrm{kg} / \mathrm{m}^{3}\right)\end{array}$ & $\begin{array}{l}\text { Superplasti } \\
\text { cizer }\end{array}$ & $\begin{array}{l}\text { Compressive } \\
\text { strength (MPa)- } \\
28 \text { days }\end{array}$ & $\begin{array}{l}\text { Splitting tensile } \\
\text { strength (MPa)- } \\
28 \text { days }\end{array}$ & $\begin{array}{l}\text { Flexural } \\
\text { strength } \\
(\mathrm{MPa})- \\
28 \text { days } \\
\end{array}$ & $\begin{array}{c}\text { Modulus of } \\
\text { elasticity } \\
\text { (GPa)- } \\
28 \text { days }\end{array}$ \\
\hline $\begin{array}{l}\text { Al-Zubaid et al.[83] } \\
2017\end{array}$ & 0.45 & $\begin{array}{l}\text { Brown glass, } \\
\text { Green glass, } \\
\text { Neon glass }\end{array}$ & $11,13,15$ & $(-)$ & $(-)$ & $(-)$ & $\begin{array}{c}\text { Ref } 27.85 \\
\quad \text { Range } \\
26.35 \text { to } 18 \\
24.65 \text { to } 22 \\
28.15 \text { to } 11.20 \\
\end{array}$ & $\begin{array}{l}\text { Ref } 3.83 \\
\text { Range } \\
2.31 \text { to } 1.35 \\
3.15 \text { to } 3.4 \\
2.30 \text { to } 2.75 \\
\end{array}$ & $\begin{array}{c}\text { Ref } 4.6 \\
\text { Range } 4.3 \text { to } \\
2.75 \\
3.15 \text { to } 2.4 \\
4.33 \text { to } 3.6\end{array}$ & $(-)$ \\
\hline $\begin{array}{c}\text { Topcu et al. [81] } \\
2004\end{array}$ & & Waste glass powder & $\begin{array}{c}15,30,45 \\
60\end{array}$ & $85-100$ & $(-)$ & $(-)$ & 10 to 30 & 2 to 2.85 & 2.27 to 5 & 30 to 45 \\
\hline $\begin{array}{l}\text { Terro et al. [84] } \\
\quad 2006\end{array}$ & 0.48 & $\begin{array}{c}\text { Fine, } \\
\text { Coarse, } \\
\text { Fine and Coarse }\end{array}$ & $\begin{array}{c}10,25,50 \\
100\end{array}$ & $100-200$ & $(-)$ & $(-)$ & 15 to 45 & $(-)$ & $(-)$ & $(-)$ \\
\hline $\begin{array}{l}\text { Corinaldesi et al. } \\
\text { [85] } 2005\end{array}$ & $\begin{array}{c}\text { Ref } 0.56 \\
\text { Type 1: } 1.00 \\
\text { Type 2: } 0.67\end{array}$ & 3 Variants in 2 types & $\begin{array}{l}\text { Type } 1: 70 \% \\
\text { Type } 2: 30 \%\end{array}$ & $(-)$ & $(-)$ & $(-)$ & $\begin{array}{c}\text { Ref: near to } 30 \\
40 \text { to } 60 \\
\text { (Bell-shaped curve) } \\
40 \text { to } 60 \text { (decreases) }\end{array}$ & $(-)$ & Near to 10 & $(-)$ \\
\hline $\begin{array}{l}\text { Shao et al. [86] } \\
2000\end{array}$ & 0.75 & $\begin{array}{c}150 \mu \mathrm{m}, 75 \mu \mathrm{m}, 38 \mu \mathrm{m} \\
\text { ground glass }\end{array}$ & $3000 \%$ & $(-)$ & $(-)$ & $(-)$ & $\begin{array}{l}\text { Ref: } 20 \text { to } 25 \\
5 \text { to } 20\end{array}$ & $(-)$ & $(-)$ & $(-)$ \\
\hline Park.et al. [87] 2004 & 0.5 & $\begin{array}{c}\text { Amber, } \\
\text { Emerald green, } \\
\text { Flint }\end{array}$ & $30,50,70$ & 150 & $(-)$ & $(-)$ & 30 to 45 & $(-)$ & $(-)$ & $(-)$ \\
\hline
\end{tabular}




\subsubsection{Glass Powder}

Another waste material which is considered as an ideal one is glass, which is widely used in our day-to-day life. The increased usage of glass is due to its variable properties like mould to any shape, bright surface finish, resistance to abrasion, and durability [81]. Glass is rigid, homogenous, inert, stable, amorphous, and isotropic material. It is manufactured by combining several inorganic raw materials and undergoes a process of controlled cooling [82]. The use of waste glass in different forms can be used in the construction sector and is proved to be advantageous as it saves lots of energy and economy. Glass non-crystalline silica is found to be almost the same elements as ordinary Portland cement. However, it differs in concentrations [83] if alkali content is disregarded. The alkali content in glass is a significant disadvantage while using this for concrete production. But this can be decreased by using certain supplementary cementitious materials like Fly Ash, GGBS, and metakaolin [82]. The summarized review of glass powder in concrete is listed in Table 3.

\section{Conclusions}

Sustainable use of waste materials in aerated and foam concrete is reviewed in this paper, and the conclusions are listed below:

- Mineral admixtures like Fly ash, GGBS, Silica fume in concrete improve resistance to thermal cracking and enhance ultimate strength, durability to sulfate attack, and alkali-aggregate expansion.

- Incorporating rice husk ash in the concrete mix is found to enhance the properties, and the most appropriate percentage of replacement is identified to be $20 \%$ with cement.

- While using plastic waste in concrete, the shape of plastic aggregates influences the mix characteristics. As the percentages of replacement increase, microcracks get arrested, and thus density can be maintained in the arrange of $1200 \mathrm{~kg} / \mathrm{m}^{3}$.

- Workability is reduced while using rubber particles due to their poor adhesion. The density was discovered to be reduced by $34.6 \%$ at a $30 \%$ replacement. The compressive strength is obtained as $30 \mathrm{MPa}$ at $20 \%$ of replacement of fine aggregate with crumb rubber.

- The quarry dust is the best option for an acceptable aggregate replacement at $20 \%$ in foam concrete. The studies show a drastic increment in compressive strength and the capillary absorption is increased to $14 \%$ than conventional cement, which reduced the risk of early-age cracking.

- Fine aggregate replaced of glass powder exhibits delay in setting time at higher percentages. While using $20 \%$ of Fine aggregate substituted with foundry sand yields comparable results to the control specimen in terms of their mechanical properties

\section{REFERENCES}

[1] N. Narayanan and K. Ramamurthy. Structure and properties of aerated concrete: a review. Cement and Concrete Composites, 22(5):321-329, 2000.

[2] E. Muthu Kumar and K. Ramamurthy. Effect of fineness and dosage of aluminium powder on the properties of moist-cured aerated concrete. Construction and Building Materials, 95:486-496, 2015.

[3] Karel Mikulica, Martin Labaj, and Rudolf Hela. Rehabilitation of Floor Structures Using Foam Concrete. Pro cedia Engineering, 195:108-113, 2017.

[4] K. Ramamurthy, E. K. Kunhanandan Nambiar, and G. Indu Siva Ranjani. A classification of studies on properties of foam concrete. Cement and Concrete Composites, 31(6):388-396, 2009.

[5] Zhaoming Huang, Tongsheng Zhang, and Ziyun Wen. Proportioning and characterization of Portland cement-based ultra-lightweight foam concrete. Construction and Building Materials, 79:390-396, 2015.

[6] T. J. Chandni and K. B. Anand. Utilization of recycled waste as filler in foam concrete. Journal of Building Engineering, 19:154-160, 2018.

[7] E.K. Kunhanandan Nambiar and K. Ramamurthy. Air-void characterisation of foam concrete. Cement and Concrete Research, 37(2):221-230, 2007.

[8] E.K. Kunhanandan Nambiar and K. Ramamurthy. Influence of filler type on the properties of foam concrete.Cement and Concrete Composites, 28(5):475-480, 2006.

[9] Y.H. Mugahed Amran, Nima Farzadnia, and A. A. Abang Ali. Properties and applications of foamed concrete; a review. Construction and Building Materials, 101:9901005, 2015.

[10] Ameer A. Hilal, Nicholas Howard Thom, and Andrew Robert Dawson. On void structure and strength of foamed concrete made without/with additives. Construction and Building Materials, 85:157-164, 2015.

[11] A Peter and Claisse. Cement and cement replacement materials. Civil Engineering Materials, 18:163-176, 2016.

[12] A.M Neville," Properties of concrete, 5th Edition, Pearson Education Limited.

[13] M.S Shetty, "Concrete Technology", 6th Edition, S Chand and Company Limited.

[14] P Kumar Mehta, Paulo J M Monterio, Concrete, Microstructure, properties and materials, 4th Edition, McGraw Hill Education (India) Private Limited.

[15] R Helmuth. Fly ash in cement and concrete, Portland Cement Association. Journal of Cement and Concrete Research, 30:201-204, 1987. 
[16] Jitchaiyaphum, K., Sinsiri, T., \& Chindaprasirt, P. Cellular lightweight concrete containing pozzolan materials. Procedia Engineering, 14, 1157-1164, 2011.

[17] L. A. Fraay, J. M. Bijen, and Y. M. de Haan. The reaction of fly ash in concrete a critical examination. Cement and Concrete Research, 19(2):235-246, 1989.

[18] J. Papayianni and T. Valiasis. Residual mechanical properties of heated concrete incorporating different pozzolanic materials. Materials and Structures, 24(2):115$121,1991$.

[19] V Bilodeau, K E Sivasundaram, V M Painter, and Malhotra. Durability of Concrete incorporating High Volumes of Fly Ash from Sources in the U. S.A., Materials Journal, 91(10):3-12, 1994.

[20] H.T.Cao, L Bucea, B.Wortley, V. Sirivivatnanon, Corrosion behaviours of steel embedded in Fly ash blended cements, ACI special -145,215-228(1994).

[21] Nixon, P. J., Page, C. L., Bollinghaus, R., \& Canham, I. The effect of a Pfa with a high total alkali content on pore solution composition and alkali silica reaction. Magazine of Concrete Research, 38(134), 30-35,1986.

[22] Ganesh Babu, K., \& Sree Rama Kumar, V. Efficiency of GGBS in concrete. Cement and Concrete Research, 30(7), 1031-1036, 2000.

[23] Barnett, S., Soutsos, M., Millard, S., \& Bungey, J. Strength development of mortars containing ground granulated blast-furnace slag: Effect of curing temperature and determination of apparent activation energies. Cement and Concrete Research, 36(3), 434-440, 2006.

[24] S Arivalagan. Sustainable Studies on Concrete with GGBS as a Replacement Material in Cement. Jordan Journal of Civil Engineering, 8(3):263-270, 2014.

[25] Li, G., \& Zhao, X. Properties of concrete incorporating fly ash and ground granulated blast-furnace slag. Cement and Concrete Composites, 25(3), 293-299, 2003.

[26] D. Etrodedroit D, Michigam, ACI 2026 IR 67. GGBS as a cementatiois consitunt in concrete; ACI manuel of concrete practice, Part -I-Materials and general properties of concrete, 1994.

[27] Wedding, P., Hogan, F., \& Meusel, J. Evaluation for durability and strength development of a ground granulated blast furnace slag. Cement, Concrete and Aggregates, 3(1), 40, 1981.

[28] M Roy. Hydration of blended cements containing slag, Fly ash or silica fume. In Proceedings of meeting, pages 29-29, 1987.

[29] Sakai K, Watanabe H, Suzuki M, Hamazaki K. Properties of granulated blast-furnace slag cement concrete, Proceedings of fourth international conference on fly ash, silica fume, slag, and natural pozzolans in concrete. Istanbul, Turkey: American Concrete Institute Publication, ACI-SP132, p. 1367-383, 1992.

[30] V M Sivasundaram and Malhotra. Properties of Concrete Incorporating Low Quantity of Cement and High Volumes of Ground Granulated Slag. Materials Journal, 89(6):554563.
[31] JSCE Recommendation for design and construction of concrete containing ground granulated blast furnace slag as admixture. Concrete Library of JSCE, 11, 1988.

[32] S Dubovoy, P Gebler, D Klieger, and Whiting. Effects of Ground Granulated Blast-Furnace Slags on Some Properties of Pastes, Mortars, and Concretes, Blended Cements. ASTM International sp, 897:29-48, 1986.

[33] Jiqiu Yuan, Will Lindquist, David Darwin, and JoAnn Browning. EFFECT OF SLAG CEMENT ON DRYING SHRINKAGE OF CONCRETE. ACI Materials Journal, 112(2):267-276, 2015.

[34] Sorabh Saluja, Kulwinder Kaur, Shweta Goyal, and Bishwajit Bhattacharjee. Assessing the effect of GGBS content and aggregate characteristics on drying shrinkage of roller compacted concrete, 2019.

[35] H K K M Lee, Lee, G Lee, and Kim. Autogenous shrinkage of concrete containing granulated blast furnace slag.Cement and concrete research, 36(7):1279-1285, 2006.

[36] Bahador Sabet Divsholi, Tze Yang Darren Lim, and Susanto Teng. Durability Properties and Microstructure of Ground Granulated Blast Furnace Slag Cement Concrete, 2014.

[37] Hooton, R., Feng, N., Shi, Y., \& Ding, J. Properties of concrete with ground Ultrafine phosphorus slag. Cement, Concrete and Aggregates, 22(2), 128, 2000.

[38] D B Sabet, T Y D Lim, S Teng, and Ultra. Advanced Materials Research, pages 368-373, 2012.

[39] Paulo J P Kumar Mehta and Monterio. Concrete, microstructure, properties and materials, 4th Edition, McGraw Hill Education (India) Private Limited

[40] Mazloom, M., Ramezanianpour, A., \& Brooks, J. Effect of silica fume on mechanical properties of high-strength concrete. Cement and Concrete Composites, 26(4), 347-357, 2004.

[41] Ankur Mehta and Deepankar Kumar Ashish. Silica fume and waste glass in cement concrete production: A review. Journal of Building Engineering, 29:100888-100888, 2020.

[42] Henri Kamal and Pierre-Claude Khayat, Silica Fume in Concrete--An Overview, ACI, SP-132, 835-872,1992.

[43] J. A. Larbi, A. L. A. Fraay, and J. M. J. M. Bijen. The chemistry of the pore fluid of silica fume-blended cement systems. Cement and Concrete Research, 20(4):506-516, 1990.

[44] Gruszczyński, M., \& Lenart, M. Durability of mortars modified with the addition of amorphous aluminum silicate and silica fume. Theoretical and Applied Fracture Mechanics, 107, 102526, 2020

[45] Josephin Alex, J. Dhanalakshmi, and B. Ambedkar. Experimental investigation on rice husk ash as cement replacement on concrete production. Construction and Building Materials, 127:353-362, 2016.

[46] Le.H. T, Siewet, K Ludwig H M, Synergistic effects of rice husk ash and fly ash on properties of self- compacting high-performance concrete, Proceedings of symposium on ultra-high performance concrete and nano technology for high-performance construction materials, Kerssel, 
Germany,187-195,2014

[47] Gemma Rodriguez de Sensale, Effect of rice husk ash on durability of cementitious materials, Cement and concrete composites, 32, 718-725,2010.

[48] Sang -Hwa Jung, Velu Saraswathy, Subbiah Karthick, Palanivel Kathirvel, Seung -Jun Kwon, Microstructure characteristics of Fly ash concrete with Rice husk ash and limestone powder, International Journal of concrete structures and materials, February, 2018

[49] Saraswathy. V and Sung H. W Corrosion performance of rice husk ash blended concrete, Construction and building materials,21(8),1779-1784, 2007

[50] Ganesan K, Rajagopal K, Thangavel K, Rice husk ash blended cement; assessment of optimal level of replacement for strength and permeability properties of concrete, Construction and building materials,22, 1675-1683, 2008.

[51] Kathirvel P, Saraswathy V, Karthik S P and Sekar A.S.S, Strength and durability properties of quaternary cement concrete made with fly ash, rice husk ash and limestone powder,38(3),589-598, 2013.

[52] Bhogayata, A. C., \& Arora, N. K. Fresh and strength properties of concrete reinforced with metalized plastic waste fibers. Construction and Building Materials, 146, 455-463, 2017.

[53] Johannesson, B., \& Utgenannt, P. Microstructural changes caused by carbonation of cement mortar. Cement and Concrete Research, 31(6), 925-931, 2001.

[54] Semiha Akçaözog־lu, Cengiz Duran Atis,, and Kubilay Akçaözog lu. An investigation on the use of shredded waste PET bottles as aggregate in lightweight concrete. Waste Management, 30(2):285-290, 2010.

[55] Yun Wang Choi, Dae Joong Moon, Yong Jic Kim, and Mohamed Lachemi. Characteristics of mortar and concrete containing fine aggregate manufactured from recycled waste polyethylene terephthalate bottles. Construction and Building Materials, 23(8):2829-2835, 2009.

[56] Yun-Wang Choi, Dae-Joong Moon, Jee-Seung Chung, and Sun-Kyu Cho. Effects of waste PET bottles aggregate on the properties of concrete. Cement and Concrete Research, 35(4):776-781, 2005.

[57] S. C. Kou, G. Lee, C. S. Poon, and W. L. Lai. Properties of lightweight aggregate concrete prepared with PVC granules derived from scraped PVC pipes. Waste Management, 29(2):621-628, 2009.

[58] Rafat Siddique, Jamal Khatib, and Inderpreet Kaur. Use of recycled plastic in concrete: A review. Waste Management, 28(10):1835-1852, 2008.

[59] O. Yazoghli Marzouk, R. M. Dheilly, and M. Queneudec. Valorization of post-consumer waste plastic in cementitious concrete composites. Waste Management, 27(2):310-318, 2007.

[60] Nabajyoti Saikia and Jorge de Brito. Waste polyethylene terephthalate as an aggregate in concrete. Materials Research, 16(2):341-350, 2013.

[61] Malek Batayneh, Iqbal Marie, and Ibrahim Asi. Use of selected waste materials in concrete mixes. Waste
Management, 27(12):1870-1876, 2007.

[62] Zainab Z. Ismail and Enas A. AL-Hashmi. Use of waste plastic in concrete mixture as aggregate replacement. Waste Management, 28(11):2041-2047, 2008.

[63] Mercante, C. Alejandrino, J. P. Ojeda, J. Chini, C. Maroto, and N. Fajardo. Mortar and concrete composites with recycled plastic: A review. Science and Technology of Materials, 30:69-79, 2018.

[64] Sara Sgobba, Giuseppe Carlo Marano, Massimo Borsa, and Marcello Molfetta. Use of rubber particles from recycled tires as concrete aggregates for Engineering Applications. In Proceedings of Second International Conference on Sustainable Construction materials and technologies, 2010.

[65] F. Angelin, E. J. P. Miranda, J.M.C. Dos Santos, R. C. C. Lintz, and L. A. Gachet-Barbosa. Rubberized mortar: The influence of aggregate granulometry in mechanical resistances and acoustic behavior. Construction and Building Materials, 200:248-254, 2019.

[66] Andressa F. Angelin, Rosa C. Cecche Lintz, Luísa A. Gachet-Barbosa, and Wislei R. Osório. The effects of porosity on mechanical behavior and water absorption of an environmentally friendly cement mortar with recycled rubber. Construction and Building Materials, 151:534-545, 2017.

[67] Marcos Lanzón, Veerle Cnudde, Tim De Kock, and Jan Dewanckele. Microstructural examination and potential application of rendering mortars made of tire rubber and expanded polystyrene wastes. Construction and Building Materials, 94:817-825, 2015

[68] Obinna Onuaguluchi and Daman K. Panesar. Hardened properties of concrete mixtures containing pre-coated crumb rubber and silica fume. Journal of Cleaner Production, 82:125-131, 2014.

[69] Blessen Skariah Thomas and Ramesh Chandra Gupta. Properties of high-strength concrete containing scrap tire rubber. Journal of Cleaner Production, 113:86-92, 2016.

[70] Laukaitis, R. Žurauskas, and J. Kerien. The effect of foam polystyrene granules on cement composite properties. Cement and Concrete Composites, 27(1):41-47, 2005.

[71] Schankoski, R. A., Pilar, R., Prudêncio, L. R., \& Ferron, R. D. Evaluation of fresh cement pastes containing quarry by-product powders. Construction and Building Materials, 133, 234-242, 2017.

[72] Jose, S. K., Soman, M., \& Evangeline, Y. S. Quarry fines: An ideal material for the manufacture of foamed concrete. Asian Journal of Civil Engineering, 22(2), 241-247, 2020.

[73] Meisuh, B. K., Kankam, C. K., \& Buabin, T. K. Effect of quarry rock dust on the flexural strength of concrete. Case Studies in Construction Materials, 8, 16-22, 2018.

[74] G. Medina, I. F. Sáez del Bosque, M. Frías, M. I. Sánchez de Rojas, and C. Medina. Durability of new recycled granite quarry dust-bearing cements. Construction and Building Materials, 187:414-425, 2018.

[75] Siong Kang Lim, Cher Siang Tan, Bo Li, Tung-Chai Ling, Md. Uzzal Hossain, and Chi Sun Poon. Utilizing high volumes quarry wastes in the production of lightweight foamed concrete. Construction and Building Materials, 
$151: 441-448,2017$.

[76] Siddique, R., Schutter, G. D., \& Noumowe, A. Effect of used-foundry sand on the mechanical properties of concrete. Construction and Building Materials, 23(2), 976-980, 2009.

[77] Anthony Torres, Laura Bartlett, Cole Pilgrim, Effect of foundry waste on the mechanical properties of Portland cement concrete, Construction and Building materials, 135,674-681,2017.

[78] G. Ganesh Prabhu, Jung Hwan Hyun, Yun Yong Kim, Effects of foundry sand as fine aggregate in concrete production, construction and building materials, 70,514-521,2014

[79] Thiruvenkitam Manoharan, Dhamothiram Laksmanan, Kaliyannan Mylsamy, Pandian Sivakumar, Anirbid Sircar," Engineering properties of concrete with partial utilization of used foundry sand", Waste Management,71,454-460,2018

[80] Gritsada Sua-iam, Natt Makul, Shanshan Cheng, Prakasit Sokrai, Workability and compressive strength development of self-consolidating concrete incorporating rice husk ash and foundry sand waste-a preliminary experimental study, Construction and building materials,228,116813,2019.

[81] Ilker Bekir Topçu and Mehmet Canbaz. Properties of concrete containing waste glass. Cement and Concrete Research, 34(2):267-274, 2004.

[82] Matos, A. M., \& Sousa-Coutinho, J. Durability of mortar using waste glass powder as cement replacement Construction and Building Materials, 36, 205-215, 2012.

[83] Aseel B. Al-Zubaid, Kadum Muttar Shabeeb, Aynoor Ibrahim Ali, Study the effect of recycled glass on the mechanical properties of green concrete, International Conference on technologies and materials for renewable energy, environment and sustainability, TMREES17, 21-24, 2017.

[84] Mohamad J Terro, Properties of concrete made with recycled crushed glass at elevated temperatures, Building and Environment,41, 633-639, 2006.

[85] V Corinaldesi, G Gnappi, G Moriconi, A Montener, Reuse of ground waste glass as aggregate of mortars, Waste Management, 25, ,197-201, 2005.

[86] Yixin Shao, Thibaut Lefort, Shylesh Moras, Damian Rodriguez, Studies on concrete containing ground waste glass, Cement and concrete research,30,91-100, 2000.

[87] Seung Bum Park, Bong Chun Lee, Jeong Hwan Kim, Studies on mechanical properties of concrete containing waste glass aggregate,34(12), 2181-2189, 2004. 